\title{
Mars Explorers: A Science Inquiry-Based Learning Project in Preschool
}

\author{
Isabel Zudaire ${ }^{1}$ (D) $\cdot$ Raquel Buil $^{2} \cdot$ Irantzu Uriz $^{1}$ (D) María Napal $^{1}$ (D)
}

Accepted: 15 November 2021 / Published online: 12 December 2021

(c) The Author(s) 2021

\begin{abstract}
Inquiry-based science education has become one of the most effective methodologies to learn science; however, proposals in preschool are scarce. Different factors are responsible for this situation, such as the low self-confidence of teachers to teach science and the belief that young children are unable to develop certain reasoning skills. This study reports the implementation of an inquiry-based science project in a preschool setting, in the context of a preservice teacher's school placement. The project aimed to promote the development of basic and integrated scientific skills, enhance acquisition of conceptual knowledge and make the students enjoy while learning science. The intervention is described thoroughly and illustrated with examples from the real implementation of the theoretical IBSE sequence. At the beginning of the proposal, the students received a hypothetical letter from the astronaut Pedro Duque, in which they were asked for help to plan his trip to living on Mars, a cold planet, with only frozen and saltwater. After some introductory POE (predict, observe, and explain) experiences on the perception of temperature and activities with fresh and saline water, the students performed a piece of research: growing lettuce in four different conditions, combining two variables: temperature and the salinity of water. As the project developed, the students progressively gave better descriptions and justifications, and also showed great interest in performing more "research experiments". For the preservice teacher, the project provided an excellent opportunity to implement academic knowledge in school practice.
\end{abstract}

Keywords Inquiry-based science education - Life conditions · POE (predictobserve-explain) strategy $\cdot$ Preschool science education $\cdot$ Scientific skills · Temperature

Isabel Zudaire

mariaisabel.zudaire@unavarra.es

1 Science Department, Public University of Navarre (UPNA), Arrosadia Campus, 31006 Pamplona, Spain

2 Public University of Navarre (UPNA), Arrosadia Campus, 31006 Pamplona, Spain 


\section{Résumé}

L'enseignement scientifique basé sur le questionnement est devenu l'une des méthodologies les plus efficaces pour l'apprentissage des sciences; cependant, les propositions à l'école maternelle sont rares. Différents facteurs sont responsables de cette situation, tels que le manque de confiance en soi des enseignants pour enseigner les sciences et la croyance que les enfants sont incapables de développer certaines compétences de raisonnement. Cet article présente la mise en oeuvre d'une séquence d'enseignement chez les enfants, pendant le stage d'un enseignant en formation. L'objectif visait à promouvoir le développement de compétences scientifiques fondamentales et intégrées, d'améliorer l'acquisition de connaissances conceptuelles et de donner aux élèves le plaisir d'apprendre les sciences. L'intervention est décrite en détail, montrant des exemples réels en salle de classe, ainsi que la description théorique. Pour commencer le projet, les élèves ont reçu une lettre hypothétique de l'astronaute Pedro Duque, dans laquelle celui-ci leur demandait de l'aider à planifier leur voyage vers Mars, une planète froide, avec de l'eau glacée et salée. Après diverses activités sur la perception de la température et des expériences avec de l'eau douce et l'eau salée, établies selon un schéma POE (prédire, observer et expliquer), les étudiants ont mené une recherche: culture de la laitue dans quatre conditions différentes, combinant deux variables, la température et la salinité de l'eau. Tout au long du projet, les étudiants ont progressivement fourni de meilleures descriptions et justifications, et ont montré un grand intérêt à mener plus d' "expérimentations". Concernant l'enseignant stagiaire en formation, le projet lui a offert une excellente occasion d'appliquer les connaissances académiques dans la pratique dans le milieu scolaire.

\section{Resumen}

La enseñanza de las ciencias basada en la indagación se ha convertido en una de las metodologías más eficaces para aprender ciencias; sin embargo, las propuestas en educación infantil son escasas. Diferentes factores son los responsables de esta situación, como la baja autoconfianza de los maestros para enseñar ciencias y la creencia de que el alumnado infantil es incapaz de desarrollar ciertas habilidades de razonamiento. En este artículo se presenta la implementación de una secuencia de indagación en infantil, durante las prácticas escolares de una maestra en formación. El objetivo fue promover el desarrollo de habilidades científicas básicas e integradas, mejorar la adquisición de conocimientos conceptuales y hacer que los estudiantes disfrutaran aprendiendo ciencias. La intervención se describe detalladamente, mostrando ejemplos de la implementación real de la secuencia teórica de indagación. Al inicio, el alumnado recibió una hipotética carta del astronauta Pedro Duque, en la que se les pedía ayuda para planificar su viaje a Marte, un planeta frío, con agua helada y salada. Tras diversas actividades sobre la percepción de la temperatura y experiencias con agua dulce y salada, siguiendo un esquema POE (predecir, observar y explicar), los estudiantes realizaron una investigación: cultivar lechugas en cuatro condiciones diferentes, combinando dos variables, temperatura y salinidad del agua. A lo largo del proyecto, los estudiantes fueron capaces de realizar progresivamente mejores descripciones y justificaciones, y mostraron gran interés en realizar más "ex- 
perimentos". Para la maestra en formación, el proyecto brindó una excelente oportunidad para aplicar el conocimiento académico en la práctica escolar.

\section{Introduction}

Learning science in the early years is feasible and beneficial for children. Going further, young children have "the right" to learn science in order to make sense of their world (Larimore, 2020). Learning science satisfies preschoolers' natural curiosity and sustains their interest in exploring the world around them. It also implies the development of process skills, such as observing, predicting, making comparisons, and simple abstract abilities, such as asking questions, drawing conclusions, etc. (Greenfield et al., 2009). It also favors the development of the social-emotional and language domains (Larimore, 2020). Lastly, satisfactory science-learning experiences in the early years result in increased self-efficacy and interest in science in later learning (Artigue et al., 2012; Patrick et al., 2009).

Science is included in most preschool -curricula and government recommendations (COSCE, 2011; Expert Group on Science Education, 2015; National Research Council, 2013); these standards include topics ranging from physics and life science to Earth and space science. However, science is still hardly present in early years classrooms: while preschool teachers claim to perform science activities, in most cases these are only free play activities, not purposefully designed to do science (which is surprising, considering that classrooms are often arranged in corners or environments, some of which are frequently devoted to science activities) (Early et al., 2010; Piasta et al., 2014; Tu, 2006; Uriz et al., 2021).

Many factors may explain the present situation of science teaching in early years' education. Firstly, in some countries, preschool curricula only specify the contents and the general objectives, without any guideline to implement science in the classroom, and, linked to that, schools are not furnished with adequate resources. Secondly, it is still believed that children at this stage lack mental structures to acquire abstract ideas (Inhelder \& Piaget, 1964 cited in Gelman et al., 2010, p. 2). Thirdly, some researchers highlight the low self-confidence of teachers to teach science in the early years as one of the most important causes of this limited presence of science in preschool classrooms (Gomes \& Fleer, 2020). Teachers feel uncomfortable with science due to their insufficient conceptual knowledge about science and their limited pedagogical content knowledge (Thulin \& Redfors, 2017).

Thus, research on preschool science teaching has emphasized the need to improve science teaching in the training programs of future teachers (Cantó et al., 2016). Therefore, some authors suggest the convenience of exposing trainee teachers to learning and training practices that involve "doing science", such as inquiry learning (Eckhoff, 2017). Actively participating in integrated science experiences, within the supportive environment of a teacher education program, may help prospective teachers to understand what science is, how it is done, and lose the fear to implement this type of methodologies in the classroom, which are very often treated in university teaching from an overly theoretical point of 
view and disconnected from real practice. A possible approach is the implementation of science activities during preservice teachers' school placement, as is the case of the work presented in this paper.

\section{Inquiry-Based Science Learning}

Inquiry-based science education (IBSE) has become one of the most effective methodologies to learn science (Couso, 2014). IBSE follows the scientific method and proposes learning activities close to the children's context; it includes experimental practices and focuses on the development of argumentative skills and the construction of models (Artigue et al., 2012). In IBSE, teachers guide and facilitate the learning process by providing materials, organizing activities and mainly asking questions to promote students' reasoning. Likewise, teachers do not convey explicit content to be memorized but guide children's attention to foster deeper understanding (Worth, 2010).

An IBSE project starts with a new experience or question. This experience should be close to the children's context, although unexpected, without an obvious response and challenging enough to promote curiosity and grasp interest (Platon European Project, 2016). For example, the discovery of worms in a walk to a park near the school is sufficient to inspire an inquiry project that allows working on science concepts and scientific skills for a whole year (Fine \& Desmond, 2015). During these science projects, even very young children are able to give some kind of explanation. To facilitate this engagement with the task, it is recommended to check students' previous knowledge about the subject and to use it to inform the design of the following activities (Napal \& Zudaire, 2019). Then, working with these existing ideas, children could make a prediction, perform observation activities, and plan and conduct simple experiments to solve the proposed question. After collecting and interpreting data, students draw conclusions that must be contrasted with the initial prediction or hypothesis (Pedaste et al., 2015)

As in "real" science conducted by scientists, the inquiry cycle at school usually exhibits a flexible, non-linear structure (Domènech-Casal, 2019, p. 27; Worth, 2010). Unexpected findings may demand new hypotheses or the need to plan new experiments. Teachers must be prepared to be flexible and embrace changes, although this initial scheme can be very useful for the initial design of the proposal.

Together with science concepts and practices, the IBSE methodology may be useful to promote basic large and small motor control, learning of vocabulary, and communication skills (Samarapungavan et al., 2011; Worth, 2010).

For early young children, IBSE should be introduced progressively, e.g., through simple POE (predict-observe-explain) sequences (White \& Gunstone, 2014). POE sequences are useful to know students' ideas at the beginning of a topic and to initiate students into scientific reasoning by developing these three basic science skills (Liang, 2011). 
While IBSE has been frequently implemented in middle and high school, publications reporting inquiry-based science proposals in preschool are scarce. Nevertheless, successful sequences have been carried out in preschool classrooms, where children have effectively grasped concepts such as water flows, animal behavior and adaptation, or magnetism, while simultaneously developing key scientific skills (Fine \& Desmond, 2015; Johnson et al., 2019; Samarapungavan et al., 2008, 2011; Van Hook \& Huziak-Clark, 2007).

Taking into account both the benefits of IBSE and potential difficulties that teachers may face, the main goal of this study was to design, implement and validate a guided IBSE sequence, in the context of the training of a preservice teacher. The activities are presented in a descriptive way, in combination with theoretical teaching models.

\section{Methodology}

\section{Research Context and Participants}

The project was implemented during the preservice teacher's school placement, in a public school in Navarra, in Northern Spain. The researchers obtained informed consent from the school principal to carry out the project and the collection of data.

The class was constituted of 23 preschool students (13 girls and 10 boys), aged 4-5 years. As a few children missed some of the sessions, the results of each activity are referred to the actual number of children attending that day. The students expressed themselves in their mother tongue, i.e., Spanish, and the statements shown in this paper were translated by the researchers.

The in-service teacher usually applied Project-Based Learning, and the classroom activities were arranged in corners, although preschoolers had no previous experience with IBSE. The project was contextualized on planet Mars to make use of the excitement of students with planets, following a previous project dealing with the Universe and the Solar system.

\section{Data Collection}

A descriptive case study design (Yin, 1984) was used in this project in order to report real classroom situations and to make analytical generalizations (Yin, 2009).

The project was developed for four weeks, with three sessions per week. Following a qualitative research methodology, the preservice teacher collected data from multiple sources (Creswell, 2014) to monitor the pupils' progress, including individual drawings, audio transcripts, posters, a class diary, and systematic group observation. 


\section{Data Analysis}

The analysis of the students' productions (individual students' verbatim responses, posters and drawings) served to illustrate the process of implementation of the ISBE project. The criteria for identifying and selecting the pieces was to select those fragments that provided clearest advice for teaching science through inquiry in preschool, and that provided evidence of the degree of development of process skills and non-cognitive areas.

Students' responses, were chosen and categorized by the preservice teacher and the lead author. To avoid personal bias, the third and fourth authors were involved in discussions to confirm the inferences obtained from data.

\section{Teaching and Learning Sequence}

The domain-specific theory of cognitive development claims that young children have the capacity to learn science (Gelman \& Brenneman, 2004). In contrast to traditional theories, many researchers defend that preschoolers are able to form abstract concepts and to establish cause-effect relationships (Convertini, 2021; Eshach \& Fried, 2005), as long as science activities allow for direct exploration of phenomena in everyday-life contexts (Allen et al., 2019; Gomes \& Fleer, 2020; Worth, 2010). Indeed, the order in which cognitive development materializes can be shaped by experience. Thus, practical experiences and opportunities that allow children to construct, develop and modify or change their intuitive ideas will support the development of thinking skills (Johnston, 2014).

Based on these assumptions, our IBSE project was designed to introduce conceptual knowledge and foster the development of science practices through hands-on activities of observation (e.g., the growth of lettuce, the temperature in their playground), touch (cold water), and taste (saltwater), as well as reflection activities (comparing previous ideas with new evidence).

IBSE activities were organized following the inquiry framework proposed by Pedaste et al. (2015) (see Fig. 1). They were designed by the preservice teacher (who guided the intervention) and the researchers, in close collaboration with the in-service classroom teacher.

Figure 1 synthesizes the phases, sub-phases, and activities that are described in detail below.

\section{Orientation Phase}

Inquiry is initiated and stimulated by surprising events or problematic situations that need to be solved. In our project, the school custodian brought a letter addressed to the class. In that imaginary letter, the astronaut Pedro Duque asked our children for help: he was planning a mission to Mars and asked for help to prepare for this trip. The preservice teacher chose Pedro Duque (the first Spanish astronaut) based on the fact that the preschoolers had learned about him in the previous project. 


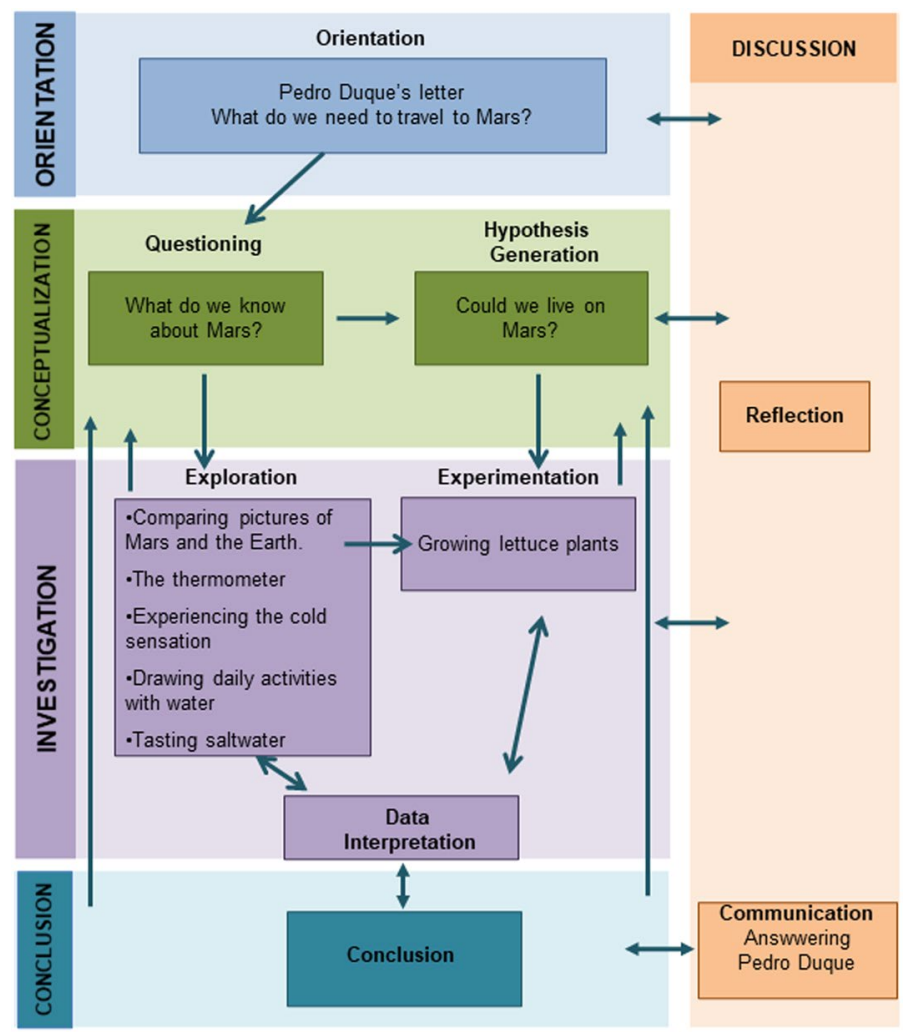

Fig. 1 IBSE model modified from (Pedaste et al., 2015)

\section{Conceptualization Phase}

This stage is focused on identifying and understanding the concepts that could explain the problem or situation considered. These concepts emerge through open questions and/or the generation of hypotheses, considering factors (i.e., variables) that could explain the stated problem.

(A) Questioning: through the question "what do we know about Mars?" children were encouraged to show their previous knowledge about the planet. Their comments were registered on a poster board that remained posted on the class wall during the entire intervention. In addition, students individually made drawings of the planet.

(B) Hypothesis generation: the children were asked "according to all you know about Mars, do you think we could live there?" To register their answers, and to promote the participation of everyone, the teacher prepared a poster board with a dichotomous answer (yes/no) and the children's names. They answered the question by making a cross in their preferred option. 


\section{Investigation Phase}

Investigation involves exploring and/or experimenting to answer the question or verify the hypothesis, which implies planning actions, and collecting and analyzing data. In our Mars project, six different activities were conducted for this purpose (see Table 1).

\section{(A) Exploration}

Comparing Pictures of Mars and the Earth The introductory research activity was based on the observation of pictures of Mars and the Earth, which were obtained from https://accessmars.withgoogle.com/. The children's comments comparing both planets were recorded on a new poster board. At the end of the activity, the teacher guided them to the poster board created in the questioning sub-phase, where their previous ideas about Mars were recorded, and compared their initial statements with their descriptions of the newly-seen pictures.

The Thermometer In order to favor the understanding of one of the differentiating environmental conditions between the two planets, temperature, an activity was planned to work on the use of the thermometer and the concept of cold and heat sensations. The next day, the teacher showed the students a model of a thermometer made of craft paper. After a whole-class discussion about the use of this instrument, the teacher showed them some pictures with different scenarios: a snowy town, a beach, a garden in spring, a garden in autumn, their own classroom, and again a picture of Mars. The teacher placed the picture of the classroom at a specific position on the thermometer and asked the students to stick the rest of the pictures, asking them: "in this picture, do we feel colder or hotter than in our classroom?" To experience spring temperature and working with a real thermometer, the teacher and the children went to the playground, and compared the temperature inside and outside the classroom using the real thermometer, following the POE scheme (prediction: Is the temperature in the playground higher or lower than in the classroom? then observation and explanation).

Experiencing the Cold Sensation To improve their knowledge of what a very low temperature means, and to connect it with the feeling of cold, some new activities were performed. Firstly, the preservice teacher prepared three buckets with water at different temperatures: warm water, water at room temperature, and water with ice cubes. Each condition was identified using a pictogram. The students were asked to put their hands into the three buckets and to tell the others which one they preferred and why. Secondly, they played a competitive game: the children had to put their hands into the bucket with freezing cold water and try to stand for as long as they could. After the competition, sitting in front of the craft paper-made thermometer, they tried to guess where the pictogram of the bucket with iced water had to be laid. After checking that Mars' temperature is even colder than the bucket with ice, the 


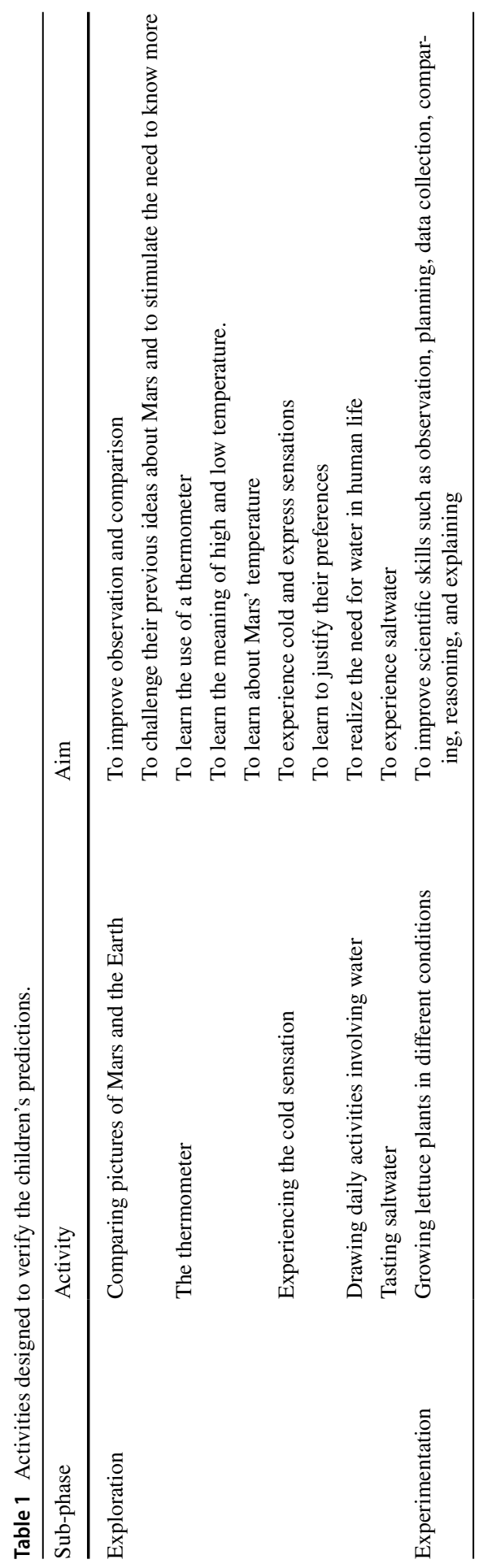


problem-posing question was: "could we stand for a long time on Mars? What could we do to survive in this cold weather?"

Experience with Saltwater To contextualize the following activities, the teacher reminded the main differences found between Mars and the Earth: in Mars, water is scarce and frozen. The children were asked to draw four different quotidian activities where they use water and to explain their drawings to their classmates. To drive the discussion, the teacher asked: "Do you think we could live without water?"

The next day, the teacher showed the children a surprising piece of news she had read in the newspaper: most of the water on Mars is saltwater. Then, they checked their previous drawings about water uses and tried to think of the possibility of doing all these things with saltwater. Then, the teacher encouraged them to plan an experience to test if they like or dislike saltwater. With the guide of the teacher, they planned the materials and a protocol to taste saltwater: spoons, cups, water with and without salt, etc.

(B) Experimentation: Growing Lettuce Unlike exploration, experimentation follows a series of organized stages, with a specific timeline, varying or maintaining different variables (Pedaste et al., 2015). According to this framework, the day after the previous exploring activities, the students were asked to remember all they had experienced. Then the teacher asked again: "Taking into account all we have learnt, do you think we could live on Mars?" After different suggestions, with the teacher's help, they decided to perform an experiment: to grow some plants of lettuce in different conditions that mimicked the temperature and water availability on Mars and the Earth. Lettuce plants would be growing:

- At room temperature $\left(20^{\circ} \mathrm{C}\right)$ and with freshwater.

- At room temperature and with saltwater (two tablespoons in $125 \mathrm{~mL}$ ).

- At cold temperature (in a freezer, $-18{ }^{\circ} \mathrm{C}$ ) and with freshwater.

- At cold temperature and with saltwater.

The students were organized into heterogeneous groups (considering drawing skills and interpersonal relationships), and each day, for 5 days, a group had to water the plants. The teacher emphasized the importance of every group doing its part to be able to build a complete life story of the lettuce. The students registered the lettuces' aspect with drawings and the teacher took daily pictures of each condition.

(C) Data Interpretation During the data interpretation sub-phase, the students synthesize the collected data and make sense of them. This scientific skill could be hard for preschoolers, due to their limited ability to sort out data and infer patterns or relationships. Therefore, the guide of the teacher is essential to help them to find patterns in the observed events.

In the project, the students reviewed the drawings and pictures from the four conditions, which were placed on a large board. The teacher encouraged them to explain what had happened to the lettuces. Despite the aid of the pictures and drawings, 
some students had difficulties orally expressing the evolution of the lettuce plants. The teacher encouraged them to dramatize lettuce growing using body language. To show that the lettuce plants were wilting, they started the performance on tiptoe with raised arms, then they started bending until they ended up lying on the ground.

\section{Conclusion Phase}

In this phase, the students had to review their initial research question or hypothesis and evaluate it based on the results. Then, the teacher showed them the register of activity Hypothesis generation ("Could we live on Mars?") and asked the children if, after the experiences with temperature and salinity and the experiment, they would keep their initial prediction.

Then a final question was asked: "how will lettuce grow on Mars?"

\section{Discussion Phase}

IBSE implies communication. Although constant dialogues and reflection were encouraged in each activity, it is essential to include a final activity to help students construct their own conclusion and communicate it. Then, the children wrote a letter, giving Pedro Duque advice for the trip. They discussed every part of the letter: salutation, presentation, body (what they had learnt, what they suggested), complimentary close, and signature.

\section{Highlights About the Role of the Teacher}

To favor concept learning, the preservice teacher designed the activities organizing concepts in a coherent way (firstly temperature, secondly saltwater, and finally both variables together), and the activities started always remembering the evidence obtained in the previous activity. In addition, during every activity, the teacher provided the opportunities to communicate about their findings, which together with favoring language development, enables construction of meanings.

Regarding scientific skills, it is argued that their development relies on many factors, such as the science content worked, the resources provided, the cognitive development of children, and, mainly, the questions that teachers ask (Hamel et al., 2021; Martens, 1999). Therefore, when working on different skills integrated with content, special attention was paid to the use of productive questions to favor the children's inquiry (Table 2).

On top of promoting curiosity, the teacher is responsible for scaffolding the activity, adapting it to the level of autonomy of the students. As such, providing templates or visual aids, such as pictograms to identify the different experimental conditions and collecting data using an organized table proved useful to enable data analysis. In addition, due to their limitations on drawing, the inclusion of lettuce pictures helps the students to understand and explain the process.

Likewise, the teacher is responsible for the management of the other non-cognitive aspects, including social interaction and motivation. During the whole proposal, she aroused the children's curiosity when suggested they wore an imaginary 
Table 2 Productive questions (Martens, 1999) to improve scientific skills.

\begin{tabular}{ll}
\hline Scientific skills & Productive questions \\
\hline Observing & What do you see here? \\
& What else can you see? \\
& What color is this lettuce? \\
Comparing & Are Mars and the Earth the same color? \\
& Do we feel colder or hotter than in our classroom? \\
& Are these three buckets similar or different? \\
Explaining & Why do you think so? \\
& Where do you feel more comfortable? With warm/cold/room temperature \\
Inferring & water? Why? \\
Planning & According to all you know about Mars, do you think we could live there? \\
& What do we need to prepare saltwater? \\
Reflecting-arguing & Can we make a list of tools needed to plant lettuce? \\
& What do you think happened to this lettuce? \\
Why do you think this group of plants has grown better than this one? & In which condition will lettuce grow best? \\
Communicating & Which condition is similar to Mars? \\
& What are we going to tell Pedro Duque? \\
& What have you learnt? \\
\hline
\end{tabular}

lab coat to work as scientists; peer-to-peer interactions were boosted by working on respectful dialogues and highlighting the importance of a good individual drawing to achieve a whole view of lettuce growing; individual identity development was promoted through the recording of individual opinions about life on Mars, water temperature and taste of saltwater.

\section{Results and Discussion}

The activities that integrate the proposal were designed from a holistic approach to preschool science education (Larimore, 2020), integrating science practices, content knowledge, and non-cognitive development. All these three dimensions are developed in each phase of the IBSE sequence, specifically targeting some of their components (Table 3). Identifying and defining these dimensions is crucial for reaching an integrated inquiry practice that becomes efficient. For preservice teachers, this analysis may be difficult at the beginning; however, this effort of globalization facilitates integrating the theory about science teaching received during their university studies and the real practice. 


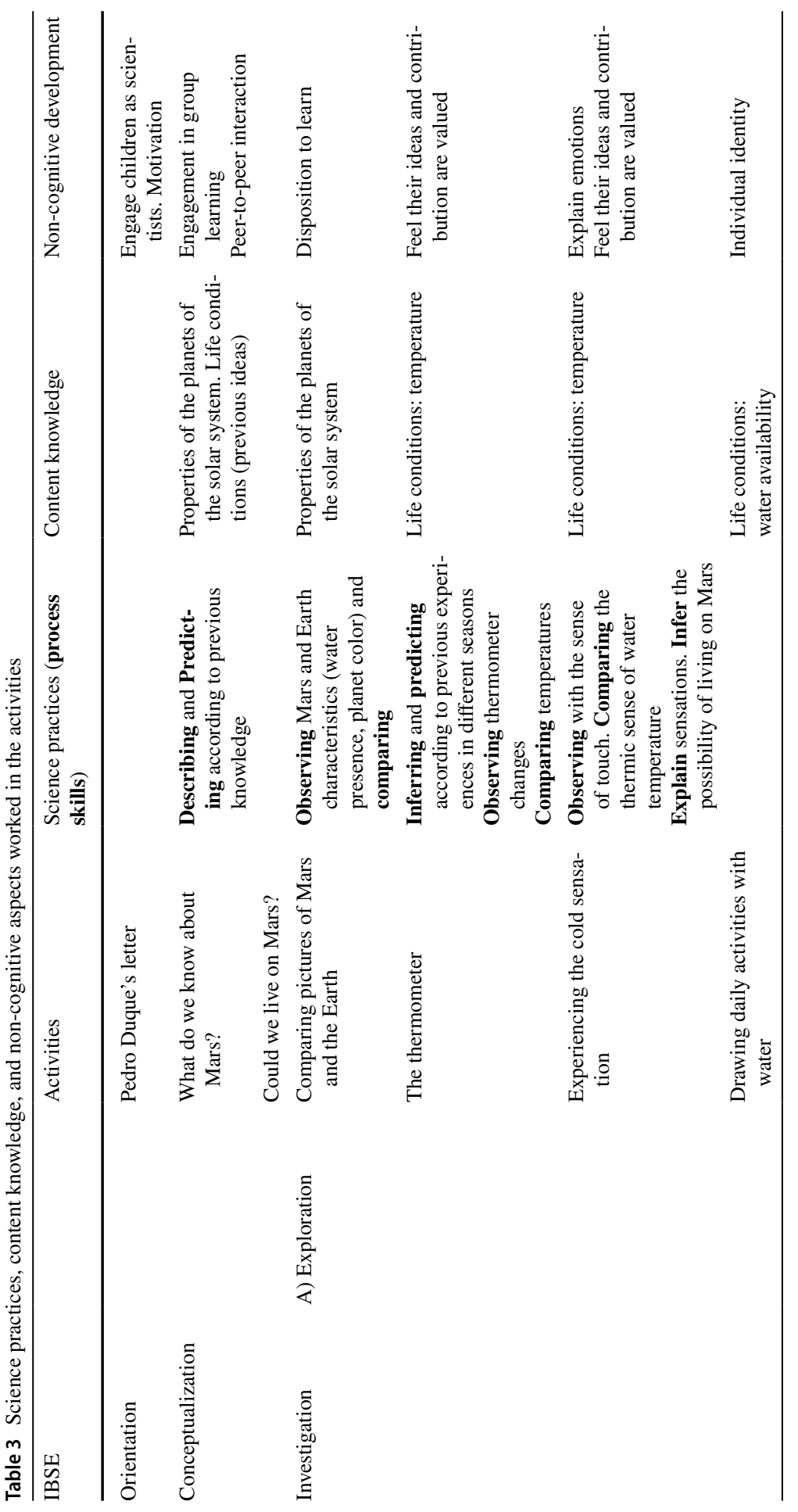




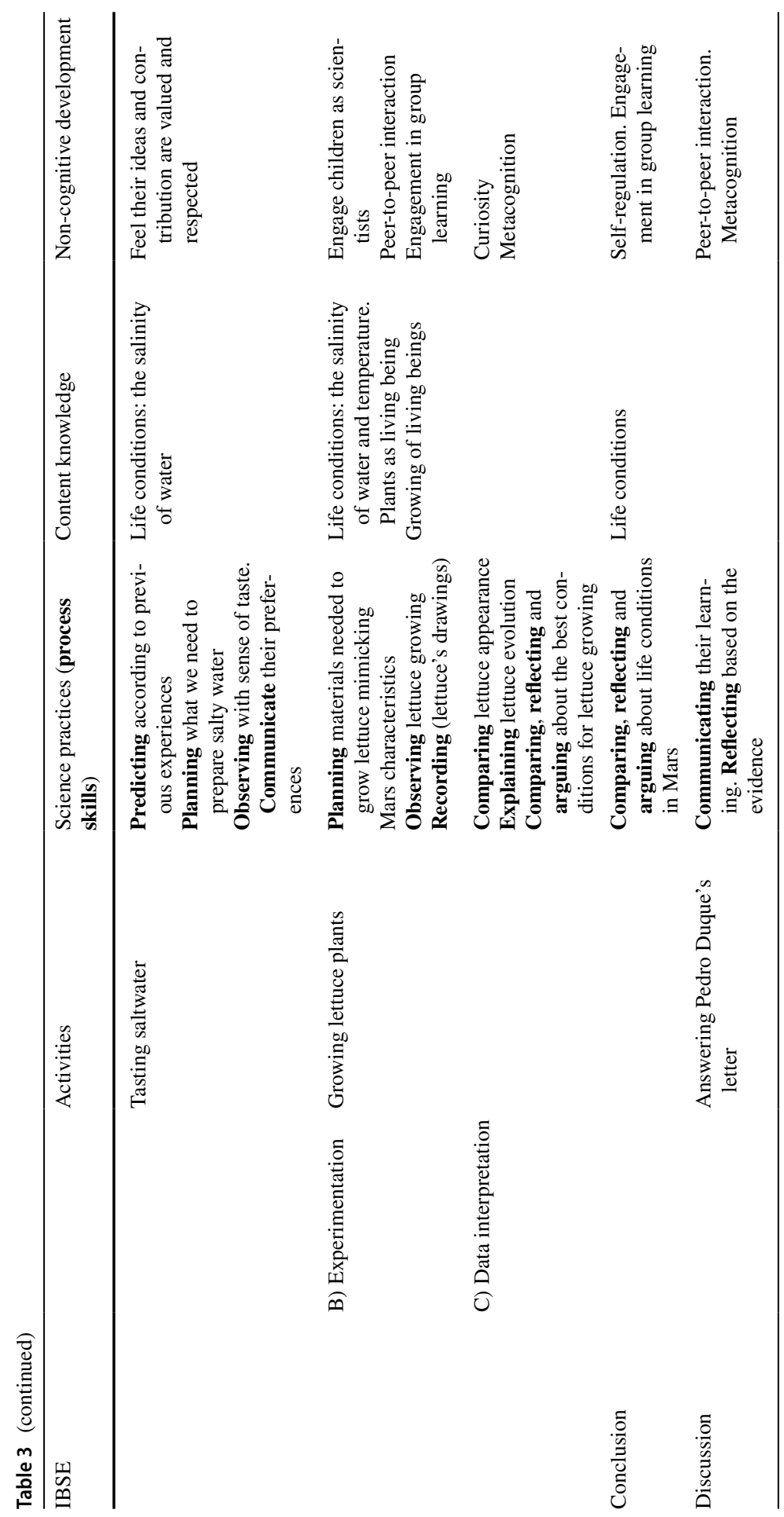



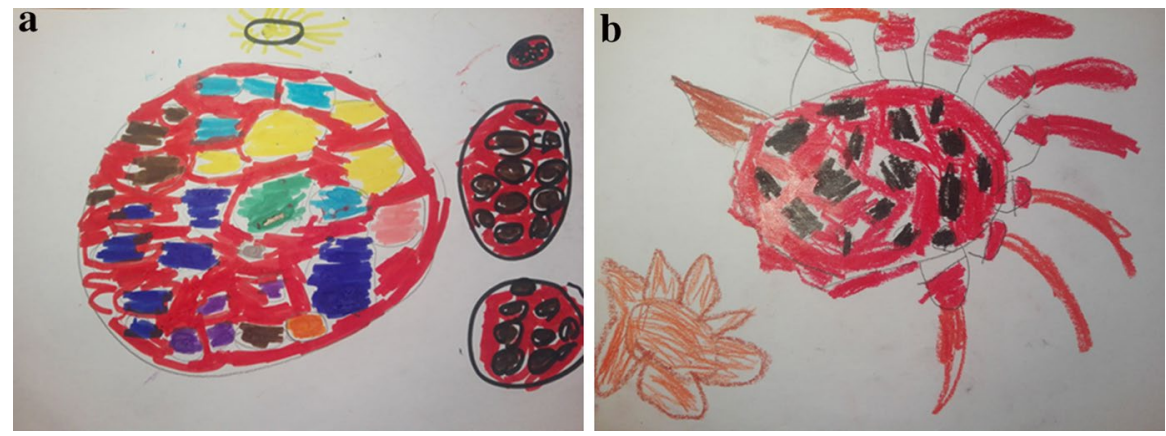

Fig. 2 a Mars colored in red, with some spots colored in brown due to the meteorites. On the left, the student drew Dad Mars, and on the right, Mum Mars, the brother, and the baby Mars. b Mars colored in red, and around it, volcanos expelling lava. The black spots were craters and, on the left, the student drew the Mars mountain

\section{Content Knowledge}

Initially, the most repeated conceptions about the planet were that Mars is made of fire, it is hot, it is red, it is covered with holes, it has volcanoes, and it has a big mountain on it (see Fig. 2). Under these assumptions, when the preservice teacher asked about the possibility of living on Mars, 8 out of 19 children answered positively.

During the exploration phase, their main surprise was to realize that they initially thought that Mars was a really hot planet but, in the pictures, they observed frozen water. The activity with the craft thermometer helps them to make their new acquired knowledge clear. Indeed, when prompted to stick in place the picture of Mars, most students pointed out the position of the snowy town's picture. Afterward, they were really surprised when the teacher placed it far from that position at the bottom of the thermometer (Fig. 3, arrow).

The activity "Experiencing the cold sensation" is a good example to confirm that young children could think about abstract concepts if science learning is based on hands-on activities. After putting their hands into the bucket with freezing cold water and observing that the pictogram of this bucket was placed on the craft thermometer higher than the Mars' picture, then they realized that Mars' temperature would be probably incompatible with life.

The second factor considered in the living being model was the need for water (see Fig. 4). When asked about the possibility of living without water, some of the answers were:

- "No, we would die of thirst, we would starve, we would be super dirty."

- "No! Because we would be dirty and the bugs would come to our faces."

- "No, because I could not have a bath."

• " "Ducks would die." 


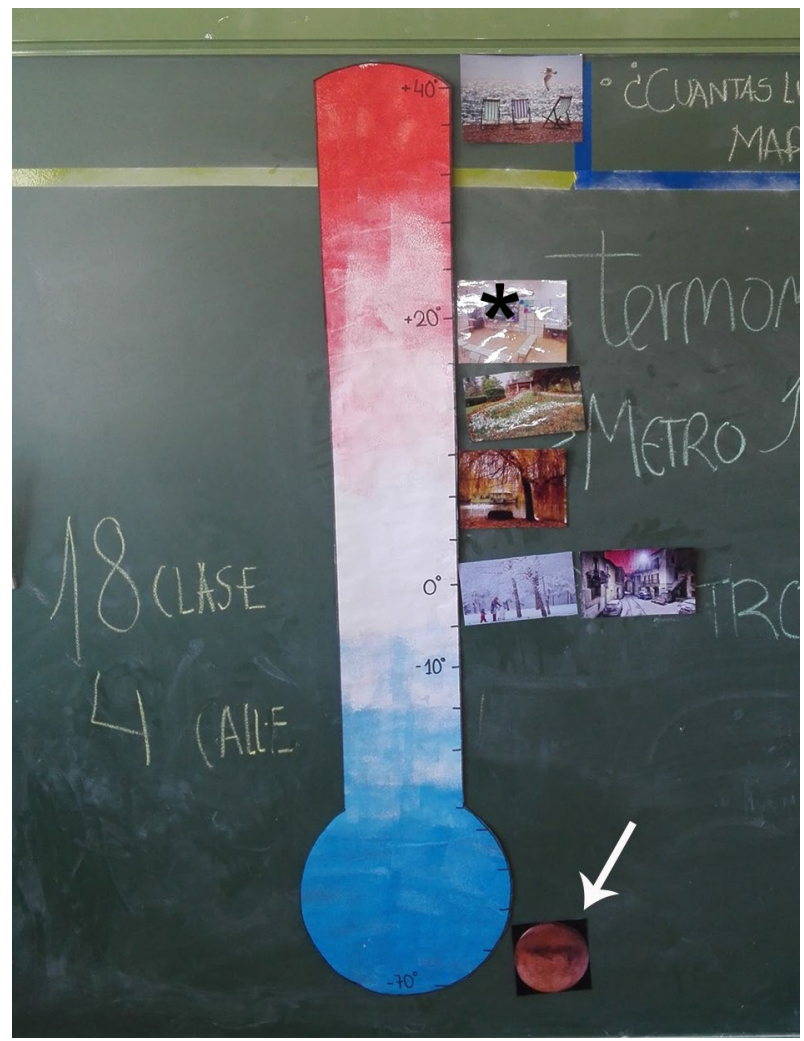

Fig. 3 Thermometer made of craft paper where the students stuck pictures with scenarios at different temperatures. Arrow: Mars picture; asterisk: classroom picture

When considering the possibility of living with saltwater, surprisingly, 15 out of 22 students considered that they could live with it (Fig. 5, column before). Again, a direct exploration (tasting saltwater), allowed them to evaluate their initial prediction and 9 students changed their minds (Fig. 5, column after).

Finally, the experimentation activity of growing lettuce (see Fig. 6) allowed to definitively build the knowledge about how living beings need specific conditions to live. This knowledge was clearly reflected in the letter they wrote to astronaut Pedro Duque (see Table 4).

Discrimination between living and nonliving beings is a common topic worked in preschool (Opfer \& Siegler, 2004; Villarroel \& Infante, 2014). Children learn that living beings grow, breathe, move, reproduce and feel emotions. Regarding plants, most published approaches are based on the identification of their different parts, seed germination, and description of plant growth (Villarroel \& Infante, 2014). However, in preschool classrooms, few proposals are based on factors influencing plant growth, working on cause-effect reasoning (Christidou \& Hatzinikita, 2006; Witt \& Kimple, 2008). In our proposal, the analysis of temperature and the need for 


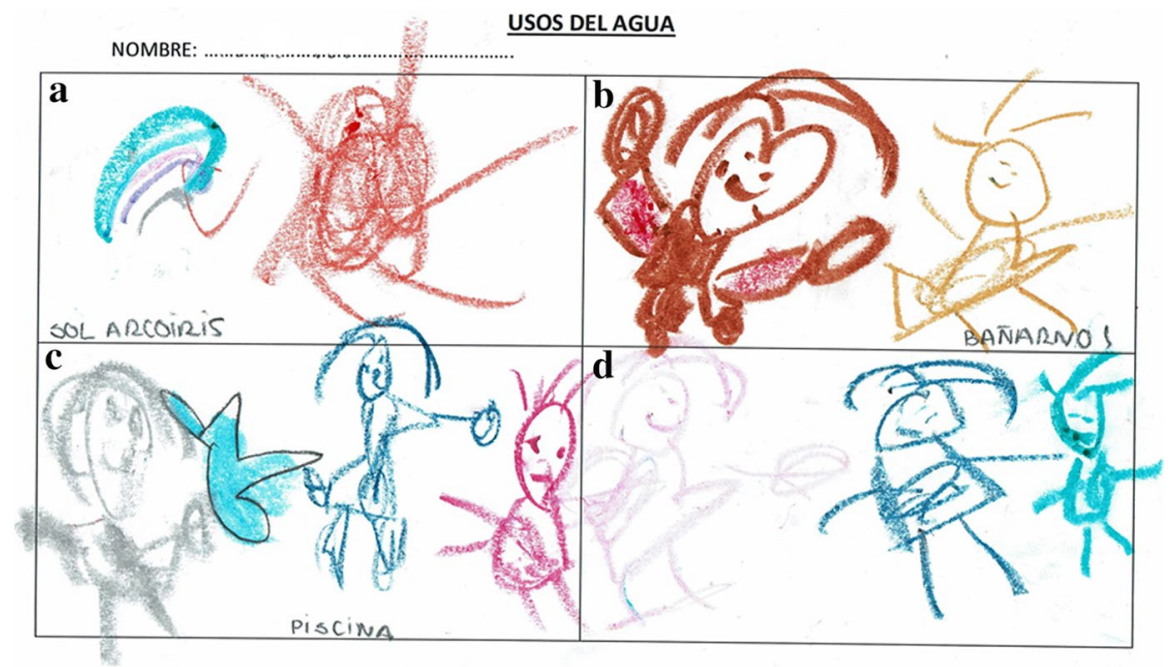

Fig. 4 Drawings showing four different uses of water: a the student drew the sun and the rainbow, b two children in the bath, $\mathbf{c}$ and $\mathbf{d}$ children in the swimming pool

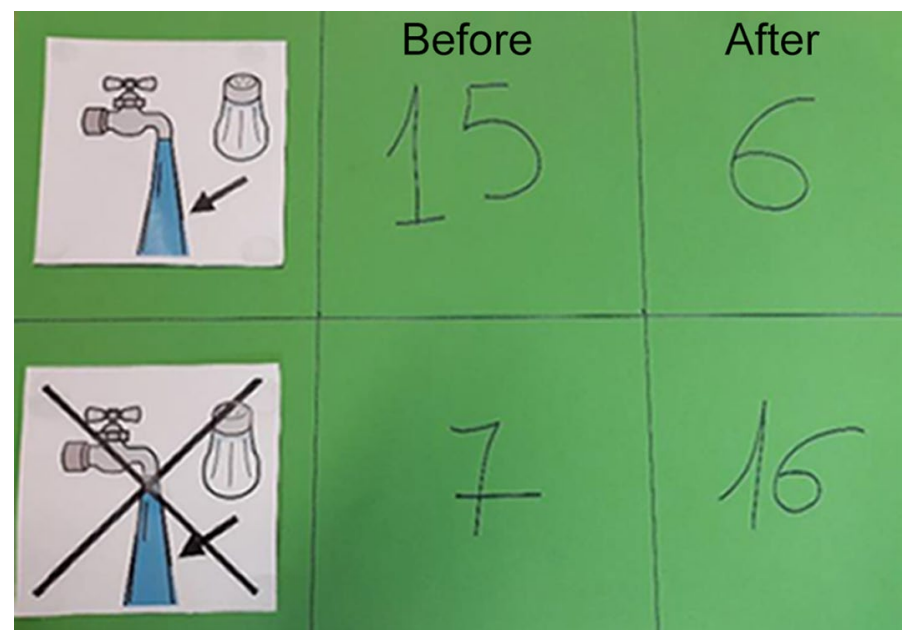

Fig. 5 The children's answers to the question "Could we do the same daily activities with saltwater as with freshwater?" before and after tasting saltwater

water allowed children to broaden the model of living beings, including the conditions needed for life (i.e., the habitat).

Moreover, later conversations suggested that the learning of this content was meaningful since the children were able to apply newly acquired content in different situations ("we can bring a pig to the classroom but we need to feed it with fresh water, not saltwater"). 


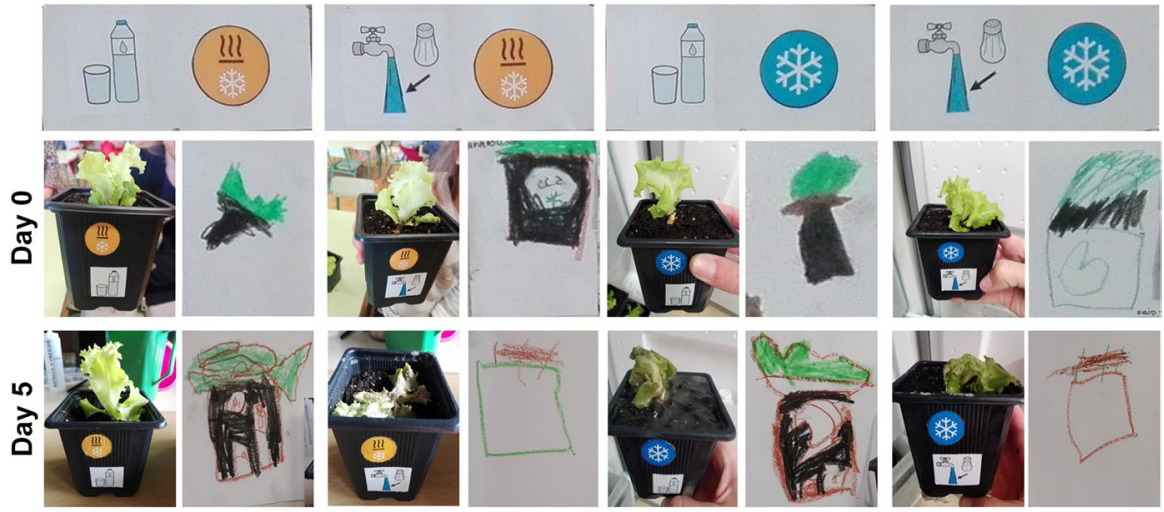

Fig. 6 Example of some pictures and drawings of the final record of lettuce evolution

Table 4 Representative sentences included in the body of the letter

\begin{tabular}{ll}
\hline Letter section & Student comments \\
\hline We tell him what we have learnt. & "Mars is really cold" \\
& "In Mars there is salt water and I didn't know" \\
"In Mars, lettuce will be cold and they will dislike saltwater" & To bring \\
What do we suggest to him? & -"A warm coat, a blanket, a polar fleece" \\
& -"A tap with fresh water" \\
& -"A lot of jars with fresh water" \\
& -"To buy a lot of food because it is not possible to grow it [lettuce]!"
\end{tabular}

\section{Scientific Skills}

We could say that the quality of the explanations, justifications, and recommendations were significantly better after the IBSE sequence. This result might be attributed to the progressive introduction of science concepts and skills progressively, firstly through POE sequences, working on basic skills (predicting, observing, comparing, communicating), carefully considering the level of autonomy/guidance that is granted and taking into account their cognitive limitations (Gelman et al., 2010). After these first steps, integrated scientific skills (experimenting, interpreting data, and concluding) were introduced.

Thus, at the beginning of the project we noted that, when the children tried to compare pictures of Mars and the Earth, they were able to describe the characteristics of both planets, but not to establish comparisons. We also noticed that the children showed more difficulties when trying to explain and reason decisions and processes. For example, when they were asked "do you think we could live on Mars?", their answers were initially limited (yes/no) and very few students were able 
to justify them. When they did, arguments justifying their option were mainly just "because".

As is confirmed in many preschool science projects, language and scientific skills develop together (Samarapungavan et al., 2011). Descriptive language is needed to express comparisons and describe phenomena, and concept understanding requires the use of a more accurate language to communicate the knowledge (Gelman et al., 2010, pp. 37-39). Thus, the preservice teacher attempted to scaffold this step by pointing out the differences and similarities between both planets. She asked comparison questions that encouraged the use of "the same as" and "different than" expressions (Table 2).

Different instruments were used to favor cause-and-effect reasoning, such as the use of a table to collect data, the daily observation of the lettuce, the pictograms, the pictures, and their drawings. All activities helped them to identify patterns in the lettuce's growth and then to improve their ability to explain the process (Table 5).

As a result of these strategies, by the end of the project they were able to provide better justifications (e.g., "could we live on Mars?", "No, my coat is not so warm"). Although some explanations could seem absurd (e.g., "what could we do to live on Mars?" "Become ice cubes, or carrying a tap with fresh water"), teachers have to consider that, when teaching science, we look for valid answers, not the right answers. Thus, these answers were well-founding, since they are based on the evidence: Mars' temperature is really cold, thus one possible solution is adaptation by mimicking the habitat. These arguments show a significant improvement in abstract reasoning, as a result of a constructive dialogue between peers and the teacher (Martin et al., 2005), thus they reflect the development of scientific thinking.

\section{Non-cognitive Development}

Together with science practices and core ideas, effective science teaching must consider a holistic approach including different domains of early childhood development (Larimore, 2020). In this way, our project favored the improvement of the fine motor domain (pouring water, mixing salt, planting lettuces), language domain (learning new vocabulary such as "freshwater"), and social-emotional domain (e.g., peer-topeer interaction, individual identity, and motivation). Concerning motivation, the students engaged in this research to satisfy the need to solve the conflict they noticed between their first ideas about Mars as a hot planet and the evidence shown in pictures (a boy said: "We are crazy, but is it hot or cold?"). Anxiety or discomfort with an anomalous observation (cognitive conflict) is condition for cognitive appraisal that leads to learning (Lee \& Byun, 2012). However, according to previous studies, cognitive conflict is not enough to provoke conceptual change (Lee \& Byun, 2012; Skoumios \& Hatzinikita, 2006; Kang et al. 2010). Indeed, conceptual change might depend not only on cognitive factors such as the recognition of conflict, but also on affective, metacognitive, and/or motivational factors (Sinatra \& Pintrich, 2003; Kang et al., 2010). Among these, situational interest has been suggested to precede and mediate individual interest, which leads to learning (Kang et al., 2010). Situational interest is changeable and can be partially controlled by teachers through task 


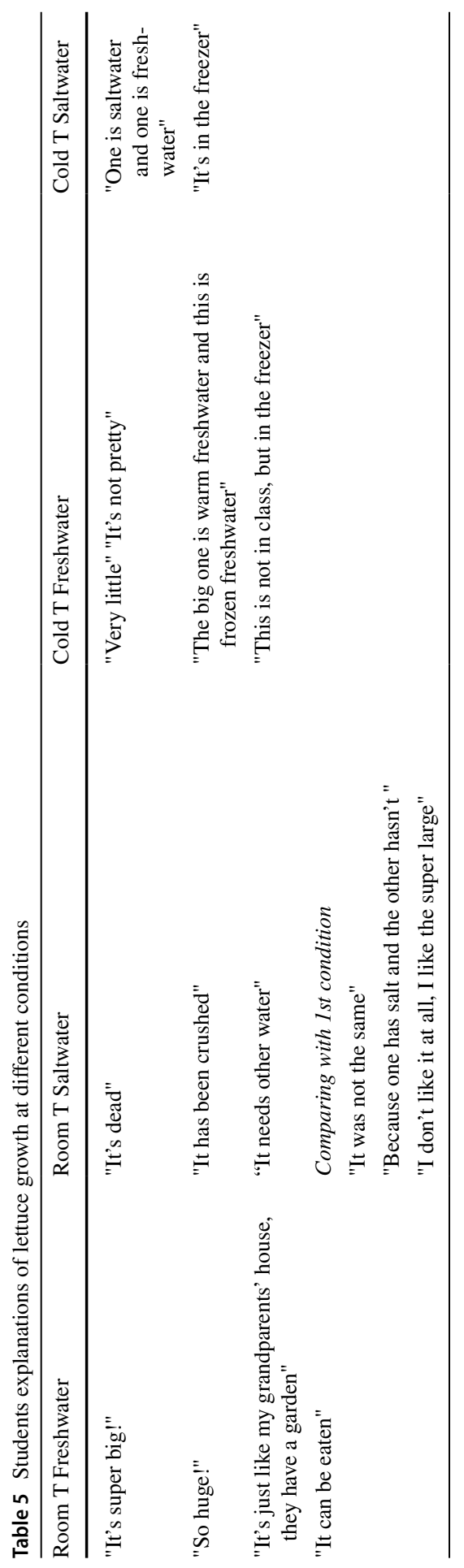


design and teaching strategies; as such, the variety of hands-on activities and the active role of the students (e.g., planning the material for the experiments) may also have contributed to their desire to learn more.

The development of this proposal had a secondary goal, which was to train the preservice teacher in science teaching. At the university, future teachers acquire theoretical knowledge about how to teach science mainly based on didactic research. However, they are usually unaware of the relevance of this knowledge on practical teaching (Feiman-Nemser, 2001 and personal communications from student teachers). In this way, teacher placements are an excellent scenario to approximate these two realities: university knowledge and school practice. In our case, the preservice teacher claimed that the main challenge in the development of this project was the need to be flexible with regard to the initial planning of the project; it was necessary to change the timing of the activities, to improvise some others to keep the students' attention, and to be always receptive to their comments in order to adapt the following activities to their demands and needs. She also mentioned that the IBSE experience helped her to understand the significance of asking productive questions in science activities. At the end of the proposal, she manifested to be willing to develop new science activities in preschool in the future, confirming that direct experience on science projects during teacher training is needed to improve their self-confidence for teaching science (Eckhoff, 2017; Gerde et al., 2018).

In summary, the development of this IBSE project showed that when children in the early years are given help and enough time to explore, discuss and reflect, they are able to develop basic and some integrated scientific skills that will be very useful for understanding their daily life and engage in science learning. In addition, this experience is an example of how the active participation of future teachers in science teaching activities is needed to integrate academic learning into the teaching practice, improving their self-confidence for science teaching.

Acknowledgments We acknowledge the in-service classroom teacher, and school direction that allowed us not only the use of different spaces but also complete freedom to organize our project without timing restrictions.

Author contributions All authors contributed to the study's conception and design. Material preparation, data collection, and analysis were performed by Raquel Buil and Isabel Zudaire. The first draft of the manuscript was written by Isabel Zudaire and all authors commented on previous versions of the manuscript. All authors read and approved the final manuscript.

Funding Open Access funding provided thanks to the CRUE-CSIC agreement with Springer Nature. No funding was received for conducting this study

Availability of data and materials All data and materials used in the manuscript support the published claims and comply with field standards.

\section{Declarations}

Conflict of interest All authors declare that they have no conflict of interest.

Consent to participate Informed consent was obtained from the school management team where the intervention was performed. 
Consent for publication We grant the Publisher an exclusive license to publish the article.

Open Access This article is licensed under a Creative Commons Attribution 4.0 International License, which permits use, sharing, adaptation, distribution and reproduction in any medium or format, as long as you give appropriate credit to the original author(s) and the source, provide a link to the Creative Commons licence, and indicate if changes were made. The images or other third party material in this article are included in the article's Creative Commons licence, unless indicated otherwise in a credit line to the material. If material is not included in the article's Creative Commons licence and your intended use is not permitted by statutory regulation or exceeds the permitted use, you will need to obtain permission directly from the copyright holder. To view a copy of this licence, visit http://creativecommons.org/licen ses/by/4.0/.

\section{References}

Allen, M., Harper, L., \& Clark, Z. (2019). Preschoolers' concepts of digestive physiology and their links with body mass index. Research in Science Education. https://doi.org/10.1007/s11165-019-9859-3

Artigue, M., Dillon, J., Harlen, W., \& Léna, P. (2012). Learning through Inquiry. In Resources for implementing inquiry in science and mathematics at school. The Fibonacci-project.eu. https://www.maiso ns-pour-la-science.org/sites/default/files/upload/learning_through_inquiry.pdf. Accessed on 7 Aug 2020

Cantó, J., De Pro, A., \& Solbes, J. (2016). ¿Qué ciencias se enseñan y cómo se hace en las aulas de educación infantil? La visión de los maestros en formación inicial. Ensenanza de Las Ciencias, 34(3), 25-50. https://doi.org/10.5565/rev/ensciencias. 1870

Christidou, V., \& Hatzinikita, V. (2006). Preschool children's explanations of plant growth and rain formation: A comparative analysis. Research in Science Education, 36(3), 187-210. https://doi.org/10. 1007/s11165-005-9006-1

Convertini, J. (2021). An interdisciplinary approach to investigate preschool children's implicit inferential reasoning in scientific activities. Research in Science Education, 51(1), 171-186. https://doi.org/10. 1007/s11165-020-09957-3

COSCE. (2011). Informe ENCIENDE Enseñanza de las Ciencas en la Didáctica Escolar para edadaes tempranas en España. In Ministerio de Ciencia e Innovación (MICINN). Rubes Ed. https://www. cosce.org/pdf/Informe_ENCIENDE.pdf. Accessed on 20 Aug 2020

Couso, D. (2014). De la moda de "aprender indagando" a la indagación para modelizar: una reflexión crítica. In XXVI Encuentro de Didáctica de las Ciencias Experimentale. (pp. 1-28). www.apice-dce. com/actas/.

Creswell, J. W. (2014). Research design: Qualitative, quantitative and mixed methods approaches (4th ed.). SAGE

Domènech-Casal, J. (2019). Enseñar a investigar. Indagación y trabajos prácticos. In Aprendizaje basado en proyectos, trabajos prácticos y controversias (pp. 1-159). Octaedro.

Early, D. M., Iruka, I. U., Ritchie, S., Barbarin, O. A., Winn, D.-M.C., Crawford, G. M., Frome, P. M., Clifford, R. M., Burchinal, M., Howes, C., Bryant, D. M., \& Pianta, R. C. (2010). How do prekindergarteners spend their time? Gender, ethnicity, and income as predictors of experiences in prekindergarten classrooms. Early Childhood Research Quarterly, 25(2), 177-193. https://doi.org/10. 1016/j.ecresq.2009.10.003

Eckhoff, A. (2017). Partners in inquiry: A collaborative life science investigation with preservice teachers and kindergarten students. Early Childhood Education Journal, 45(2), 219-227. https://doi.org/10. 1007/s10643-015-0769-3

Eshach, H., \& Fried, M. N. (2005). Should science be taught in early childhood? Journal of Science Education and Technology, 14(3), 315-336. https://doi.org/10.1007/s10956-005-7198-9

Expert Group on Science Education. (2015). Science education for responsible citizenship. DirectorateGeneral for Research and Innovation Science with and for Society. https://doi.org/10.2777/12626

Feiman-Nemser, S. (2001). From preparation to practice: Designing a continuum to strengthen and sustain teaching. Teachers College Record, 103(6), 1013-1055. https://doi.org/10.1111/0161-4681. 00141 
Fine, M., \& Desmond, L. (2015). Inquiry-based learning: Preparing young learners for the demands of the 21st century. NYSUT'S Journal of Best Practices in Education, 8, 2-11.

Gelman, R., Brenneman, K., Macdonald, G., \& Román, M. (2010). Preschool pathways to science. Facilitating scientif ways of thinking, talking, doing, and understanding. Paulh Brookes Publishing.

Gelman, Rochel, \& Brenneman, K. (2004). Science learning pathways for young children. Early Childhood Research Quarterly, 19(1), 150-158. https://doi.org/10.1016/j.ecresq.2004.01.009

Gerde, H. K., Pierce, S. J., Lee, K., \& Van Egeren, L. A. (2018). Early childhood educators' self-efficacy in science, math, and literacy instruction and science practice in the classroom. Early Education and Development, 29(1), 70-90. https://doi.org/10.1080/10409289.2017.1360127

Gomes, J., \& Fleer, M. (2020). Is science really everywhere? Teachers' perspectives on science learning possibilities in the preschool environment. Research in Science Education, 50(5), 1961-1989. https://doi.org/10.1007/s11165-018-9760-5

Greenfield, D. B., Jirout, J., Dominguez, X., Greenberg, A., Maier, M., \& Fuccillo, J. (2009). Science in the preschool classroom: A programmatic research agenda to improve science readiness. Early Education and Development, 20(2), 238-264. https://doi.org/10.1080/10409280802595441

Hamel, E., Joo, Y., Hong, S.-Y., \& Burton, A. (2021). Teacher questioning practices in early childhood science activities. Early Childhood Education Journal, 49(3), 375-384. https://doi.org/10.1007/ s10643-020-01075-Z

Inhelder, B., \& Piaget, J. (1964). The early growth of logic in the child: Classification and seriation. Routledge and Kegan Paul.

Johnson, L., McHugh, S., Eagle, J. L., \& Spires, H. A. (2019). Project-based inquiry (PBI) global in kindergarten classroom: Inquiring about the world. Early Childhood Education Journal, 47(5), 607613. https://doi.org/10.1007/s10643-019-00946-4

Johnston, J. (2014). Emergent science: Teaching science from birth to 8. Routledge.

Kang, H., Scharmann, L. C., Kang, S., \& Noh, T. (2010). Cognitive conflict and situational interest as factors influencing conceptual change. International Journal of Environmental and Science Education (IJESE), 5, 383-405.

Larimore, R. A. (2020). Preschool science education: A vision for the future. Early Childhood Education Journal, 48(6), 703-714. https://doi.org/10.1007/s10643-020-01033-9

Lee, G., \& Byun, T. (2012). An explanation for the difficulty of leading conceptual change using a counterintuitive demonstration: The relationship between cognitive conflict and responses. Research in Science Education, 42(5), 943-965. https://doi.org/10.1007/s11165-011-9234-5

Liang, J.-C. (2011). Using POE to promote young children's understanding of the properties of air. AsiaPacific Journal of Research in Early Childhood Education, 5(1), 45-68.

Martens, M. L. (1999). Productive questions: Tools for supporting constructivist learning. Science and Children, 36(8), 24-53.

Martin, D. J., Jean-Sigur, R., \& Schmidt, E. (2005). Process-oriented inquiry-A constructivist approach to early childhood science education: Teaching teachers to do science. Journal of Elementary Science Education, 17(2), 13-26. https://doi.org/10.1007/BF03174678

Napal, M., \& Zudaire, M. I. (2019). STEM. La enseñanza de las ciencias en la actualidad. Dextra Editorial S.L.

National Research Council. (2013). Next generation science standards: For states, by states. (The National Academies Press (ed.)). https://doi.org/10.17226/18290.

Opfer, J. E., \& Siegler, R. S. (2004). Revisiting preschoolers' living things concept: A microgenetic analysis of conceptual change in basic biology. Cognitive Psychology, 49(4), 301-332. https://doi.org/ 10.1016/j.cogpsych.2004.01.002

Patrick, H., Mantzicopoulos, P., \& Samarapungavan, A. (2009). Motivation for learning science in Kindergarten: Is there a gender gap and does integrated inquiry and literacy instruction make a difference. Journal of Research in Science Teaching, 46(2), 166-191.

Pedaste, M., Mäeots, M., Siiman, L. A., de Jong, T., van Riesen, S. A. N., Kamp, E. T., Manoli, C. C., Zacharia, Z. C., \& Tsourlidaki, E. (2015). Phases of inquiry-based learning: Definitions and the inquiry cycle. Educational Research Review, 14, 47-61. https://doi.org/10.1016/j.edurev.2015.02. 003

Piasta, S. B., Pelatti, C. Y., \& Miller, H. L. (2014). Mathematics and science learning opportunities in preschool classrooms. Early Education and Development, 25(4), 445-468. https://doi.org/10.1080/ 10409289.2013.817753

Platon European Project. (2016). Inquiry under the microscope. http://platon.ea.gr/content/inquiry-undermicroscope. Accessed on 7 Aug 2020 
Samarapungavan, A., Mantzicopoulos, P., \& Patrick, H. (2008). Learning science through inquiry in kindergarten. Science Education, 92(5), 868-908. https://doi.org/10.1002/sce.20275

Samarapungavan, A., Patrick, H., \& Mantzicopoulos, P. (2011). What kindergarten students learn in inquiry-based science classrooms. Cognition and Instruction, 29(4), 416-470. https://doi.org/10. 1080/07370008.2011.608027

Sinatra, G. M., \& Pintrich, P. R. (2003). Intentional conceptual change. Erlbaum. Erlbaum.

Skoumios, M., \& Hatzinikita, V. (2006). The role of cognitive conflict in science concept learning. The International Journal of Learning: Annual Review, 12(7), 185-194. https://doi.org/10.18848/14479494/CGP/v12i07/48002

Thulin, S., \& Redfors, A. (2017). Student preschool teachers' experiences of science and its role in preschool. Early Childhood Education Journal, 45(4), 509-520. https://doi.org/10.1007/ s10643-016-0783-0

Tu, T. (2006). Preschool science environment: What is available in a preschool classroom? Early Childhood Education Journal, 33(4), 245-251. https://doi.org/10.1007/s10643-005-0049-8

Uriz, I., Zudaire, I., \& Napal, M. (2021). Estudio piloto para el análisis y desarrollo de estrategias de mejora del ambiente de aprendizaje de las ciencias en Educación Infantil. 29 Encuentros de Didáctica de Las Ciencias Experimentales y $5^{a}$ Escuela de Doctorado. Oral Communication.

Van Hook, S. J., \& Huziak-Clark, T. L. (2007). Tip-to-tail: Developing a conceptual model of magnetism with kindergartners using inquiry-based instruction. Journal of Elementary Science Education, 19(2), 45-58. https://doi.org/10.1007/BF03173662

Villarroel, J. D., \& Infante, G. (2014). Early understanding of the concept of living things: An examination of young children's drawings of plant life. Journal of Biological Education, 48(3), 119-126. https://doi.org/10.1080/00219266.2013.837406

White, R., \& Gunstone, R. (2014). Probing understanding. Routledge. https://doi.org/10.4324/97802 03761342

Witt, S. D., \& Kimple, K. P. (2008). "How does your garden grow?" Teaching preschool children about the environment. Early Child Development and Care, 178(1), 41-48. https://doi.org/10.1080/03004 430600601156

Worth, K. (2010). Science in early childhood classrooms: Content and process. Early Childhood Research and Practice, Collected Papers from the SEED (STEM in Early Education and Development) Conference, 10, 1-118. http://ecrp.uiuc.edu/beyond/seed/worth.html. Accessed on 10 Aug 2020

Yin, R. K. (1984). Case study research: Design and methods. Sage.

Yin, R. K. (2009). Case study research: Design and methods (4th edn). Sage.

Publisher's Note Springer Nature remains neutral with regard to jurisdictional claims in published maps and institutional affiliations. 